\title{
PIJAT OKSITOSIN TERHADAP KUANTITAS PRODUKSI ASI PADA IBU MENYUSUI YANG MEMILIKI BAYI BERUSIA 0-6 BULAN
}

\author{
Dinni Randayani Lubis ${ }^{*}$, Legina Anggraeni² \\ 1,2Program Studi Kebidanan Universitas Binawan \\ *Korespondensi email: dinni@binawan.ac.id
}

\section{ABSTRACT OXYTOCIN MASSAGE ON THE QUANTITY OF BREAST MILK PRODUCTION FOR BREASTFEEDING MOTHERS WHO HAVE BABIES AGED 0-6 MONTHS}

Background. Breast milk is the best food given to babies especially when the baby is $0-6$ months old. Many of the benefits felt by one of them is getting the nutrients needed by the baby in his golden period. In nutrition status monitoring shows that the coverage of exclusive breastfeeding during the first 6 months by mothers is still very low, one of the reasons is the inadequacy of breast milk production. Oxytocin massage is a useful therapy in increasing the hormone prolactin so that the production of breast milk in mothers will also increase.

Purpose. To find out the effect of oxytocin massage on the increase in the production of breast milk in nursing mothers who have babies aged 0-6 months.

Method.This study uses a quasi-experimental design using one group pre-post test. The number of samples was 33 people, with the inclusion criteria being that the mother did not use drugs to increase the production of breast milk/milk booster and was willing to follow the treatment in the study, while the exclusion criteria were that the mother did not exclusively breastfeed her baby, had an areola inverter breast anatomy structure, had a history of open wounds in the back area. Prior to the oxytocin massage, respondents were measured for signs of breast milk adequacy through questionnaires filled out before and after the intervention, then the baby's weight was measured before and after the intervention using a baby's weight measurement after 4 weeks of oxytocin massage.

Results. Oxytocin massage intervention can increase the production of breast milk by 0.52 which from before the intervention by 1.12 to 1.64 after intervention. Based on the results of dependent $T$ Test obtained $P$ value 0.0001 which means there is a meaningful relationship between the administration of oxytocin massage to the increase in the production of breast milk in nursing mothers.

Conclusion. There is an influence of occult massage on the increase of breast milk production in nursing mothers who have babies aged 0-6 months.

Suggestion. Researchers are then expected to use more samples and longer periods of intervention

Keywords: Oxytocin massage, Breast Milk, Breastfeeding

\section{ABSTRAK}

Latar belakang. Air Susu Ibu (ASI) merupakan makanan yang terbaik diberikan kepada bayi terlebih saat bayi tersebut berusia 0-6 bulan. Banyak manfaat yang dirasakan salah satunya adalah mendapatkan zat gizi yang dibutuhkan oleh bayi di periode keemasannya. Pada pemantauan status gizi menunjukan bahwa cakupan pemberian ASI Ekslusif selama 6 bulan pertama oleh ibu masih sangat rendah, salah satu alasannya adalah ketidakcukupan produksi ASI. Pijat oksitosin merupakan terapi yang bermanfaat dalam meningkatkan hormone prolaktin sehingga produksi ASI pada ibu juga akan meningkat.

Tujuan Penelitian Untuk mengetahui pengaruh pemberian pijat oksitosin terhadap peningkatan produksi ASI pada ibu menyusui yang memiliki bayi berusia $0-6$ bulan.

Metode. Penelitian ini menggunakan desain kuasi eksperimen dengan menggunakan one group pre-post test. Jumlah sampel sebanyak 33 orang, dengan kriteria inklusi adalah lbu tidak menggunakan obat untuk meningkatkan produksi ASI/booster ASI dan bersedia mengikuti treatmen pada penelitian, sedangkan kriteria eklusi adalah ibu tidak menyusui bayinya secara eksklusif, memiliki struktur anatomi payudara aerola inverter, memiliki riwayat luka terbuka di area punggung. Sebelum dilakukan pijat oksitosin, responden diukur tanda-tanda kecukupan ASI melalui kuesioner yang diisi sebelum dan sesudah intervensi, selanjutnya pada bayinya akan diukur berat badan sebelum dan sesudah intervensi menggunakan penimbangan berat badan bayi setelah 4 minggu pemberian pijat oksitosin. 


\section{JKM (Jurnal Kebidanan Malahayati),Vol 7,No.3.Juli 2021, ISSN (Print) 2476-8944 ISSN (Online) 2579-762X, Hal 576-583}

Hasil. Intervensi pijat oksitosin dapat meningkatkan produksi ASI sebesar 0,52 yang dari sebelum intervensi sebesar 1,12 menjadi 1,64 setelah dilakukannya intervensi.Berdasarkan hasil Uji T dependen didapatkan hasil P-value 0,0001 yang artinya terdapat hubungan yang bermakna antara pemberian pijat oksitosin terhadap peningkatan produksi ASI pada ibu yang menyusui.

Kesimpulan. Terdapat pengaruh pemberian pijat oksitosin terhadap peningkatan produksi ASI pada ibu menyusui yang memiliki bayi berusia 0-6 bulan .

Saran. Peneliti selanjutnya diharapkan dapat menggunakan sampel yang lebih banyak dan jangka waktu pemberian Intervensi yang lebih lama.

Kata kunci: Pijat oksitosin, ASI, Menyusui

\section{PENDAHULUAN}

Data pemantauan status gizi di Indonesia pada 2017 menunjukkan cakupan pemberian ASI secara eksklusif selama 6 bulan pertama oleh ibu kepada bayinya masih sangat rendah yakni $35,7 \%$, artinya ada sekitar $65 \%$ bayi yang tidak mendapatkan ASI secara eksklusif selama 6 bulan pertama setelah lahir (Buku Saku Pemantauan Gizi, 2017). Dari data pemantauan status gizi balita pada tahun 2017 di DKI Jakarta, didapatkan hasil jumlah bayi berumur 0-5 bulan berjumlah $58,1 \%$ dan persentase bayi mendapat ASI Eklslusif sebesar 46.6 \% (Kemenkes Rl,2017).

Ketidakcukupan produksi ASI adalah alasan utama ibu untuk penghentian pemberian ASI, karena ibu merasa dirinya tidak mempunyai kecukupan produksi ASI untuk memenuhi kebutuhan bayi dan mendukung kenaikan berat badan bayi (Rahayu et al., 2015). Kurangnya rangsangan hormon prolactin dan oksitosin menyebabkan penurunan produksi dan pengeluaran ASI pada hari-hari pertama setelah melahirkan yang berpengaruh terhadap kelancaran dan produksi ASI. Salah satu cara untuk mengatasi ketidaklancaran produksi ASI dengan melakukan pemijatan pada daerah tulang belakang leher, punggung atau sepanjang tulang belakang (vertebrae) sampai tulang costae kelima sampai keenam (Suherni, dkk, 2016). Penelitian sebelumnya mengatakan adanya pengaruh antara pijat oksitosin dan endorphin mempengaruhi produksi ASI yang dilakukan pada ibu yang menyusui (Tutik, 2019). Penelitian yang sama juga didapatkan hasil adanya pengaruh pijat oksitosin terhadap pengeluaran ASI, setelah dilakukan pemijatan ASI menjadi lebih cepat keluar daripada yang tidak dilakukan pijat oksitosin (Rusdianti, 2014)

ASI yang tidak lancar dapat disebabkan oleh beragam faktor, salah satunya karena munculnya perasaan cemas dan stres yang berlebih, sehingga berdampak pada produksi ASI. Untuk membantu membuat Ibu tetap merasa tenang, nyaman dan tidak stres di masa menyusui, Ibu bisa melakukan pijat laktasi. Pijat lakstasi memicu produksi hormon oksitoksin, hormon yang berperan penting dalam proses pengeluaran ASI. Dengan dilakukannya pijat laktasi pada ibu menyusui dapat meningkatkan produksi ASI yang sangat bermanfaat terhadap pemberian ASI pada bayi, selain itu dengan adanya pijet laktasi dapat mencegah dan mengatasi bendungan ASI serta mempercepat proses involusi uteri pada ibu post partum.Beberapa penyebab kegagalan menyusui juga telah diidentifikasi dari beberapa penelitian diantaranya adalah kurangnya dukungan sosial, kontak yang kurang intensif antara ibu dan bayi, pengaruh sosial yang permisif terhadap pemberian susu formula atau penghentian menyusui, praktik komersil dari pabrik susu formula, pengenalan dini makanan pengganti ASI, pengetahuan yang kurang tentang menyusui pada ibu dan petugas kesehatan, kecemasan dan stres ibu, kurang percaya diri pada ibu untuk menyusui, berat badan bayi yang kurang, ibu malnutrisi, multi atau primipara, kontrasepsi hormonal dan temperamen bayi (Juanita, 2016).

\section{METODOLOGI PENELITIAN}

Penelitian ini menggunakan desain desain kuasi eksperimen dengan menggunakan one group pre-post test yaitu desain penelitian eksperimen yang menggunakan satu kelompok subyek serta melakukan pengukuran sebelum dan sesudah memberikan perlakukan (intervensi) pada subyek penelitian. Penelitian ini dilakukan diwilayah Kerja Kelurahan Cililitan Jakarta Timur pada tahun 2020. Jumlah sampel yang digunakan dalam penelitian ini berjumlah 33 orang. Dengan kriteria inklusi diantaranya adalah Ibu memiliki bayi berusia 0-6 bulan baik primipara maupun multipara, tidak menggunakan obat untuk meningkatkan produksi ASI/booster ASI dan bersedia mengikuti treatmen pada penelitian, sedangkan untuk kriteria eklusi adalah ibu tidak menyusui bayinya secara eksklusif, memiliki struktur anatomi payudara aerola inverter, memiliki riwayat luka terbuka di area punggung dan 
tidak bersedia untuk mengikuti treatmen pada penelitian. Sebelum dilakukan intervensi pijat oksitosin sampel diukur produksi ASI dengan menggunakan kuesioner tanda kecukupan Asi dan pada bayi diukur berat badan awal. Setelah itu dilakukanlah intervensi pijat oksitosin. Pemijatan oksitosin dilakukan oleh peneliti selama 8 kali dalam 4 minggu. Setelah selesai diberikan intervensi berupa pijat oksitosin kemudian diukur kembali produksi ASI ibu dan berat badan bayinya. Hasil dari pengukuran keduanya kemudian dibandingkan untuk mengukur pengaruh pijat oksitosin terhadap peningkatan produksi ASI.

\section{HASIL DAN PEMBAHASAN \\ Analisis Deskriptif}

Berdasarkan tabel 1 didapati hasil bahwa dari 33 responden didominasi oleh usia yang tidak berisiko yaitu sebanyak 24 responden (72,7\%) sedangkan pada usia yang berisiko terdapat sebanyak 9 responden $(27,3 \%)$. Pendidikan responden paling banyak tergolong pada pendidikan tinggi yaitu sebanyak 29 orang $(87,9 \%)$ dan pendidikan rendah dari SD-SMP sebanyak 4 orang $(12,1 \%)$. Pekerjaan responden mayoritas adalah tidak bekerja yaitu sebanyak 19 responden $(57,6 \%)$ dan sisanya 14 responden tidak bekerja $(42,4 \%)$. Untuk paritas responden didominasi oleh multipara sebanyak 19 responden $(57,6 \%)$ kemudian disusul oleh primipara sebanyak 12 respnden sebesar $36,4 \%$ dan grandemultipara 2 orang sebesar $6,1 \%$.

Tabel 1.

Karakteristik Responden Penelitian

\begin{tabular}{lcc}
\hline \multicolumn{1}{c}{ Variabel } & Frekuensi (N) & Persentase (\%) \\
\hline Usia & & \\
Berisiko (<20 tahun dan > 35 tahun) & 9 & 27,3 \\
Tidak Bersiko (20-35 tahun) & 24 & 72,7 \\
Pendidikan & & \\
Rendah (SD-SMP) & 4 & 12,1 \\
Tinggi (SMA-PT) & 29 & 87,9 \\
Pekerjaan & & \\
Tidak Bekerja & 19 & 57,6 \\
Bekerja & 14 & 42,4 \\
Paritas & & \\
Primipara & 12 & 36,4 \\
Multipara & 19 & 57,6 \\
Grandemultipara & 2 & 6,1 \\
\hline
\end{tabular}

Tabel 2.

Distribusi Frekuensi Pengalaman Menyusui, Dukungan Keluarga, Pola Istirahat dan Perawatan Payudara

\begin{tabular}{lcc}
\hline \multicolumn{1}{c}{ Variabel } & Frekuensi (N) & Persentase (\%) \\
\hline Pengalaman Menyusui & 19 & \\
Ada & 14 & 57,6 \\
Tidak & & 42,4 \\
Dukungan Keluarga & 33 & 100 \\
Ada & 0 & 0 \\
Tidak & & \\
Pola Istirahat & 23 & 69,7 \\
Baik & 10 & 30,3 \\
Kurang & & \\
Perawatan Payudara & 20 & 60,6 \\
Melakukan perawatan payudara & 13 & 39,4 \\
Tidak melakukan perawatan payudara & & \\
\hline
\end{tabular}


JKM (Jurnal Kebidanan Malahayati),Vol 7,No.3.Juli 2021,

ISSN (Print) 2476-8944 ISSN (Online) 2579-762X, Hal 576-583

Berdasarkan tabel 2 dimana data terkait data responden dimana data /pengukuran hasil diambil dari kuesioner yang di isi langsung oleh responden, maka didapatkan dari 33 responden berdasarkan pengalaman menyusui didominasi oleh responden memiliki pengalaman menyusui sebanyak 19 responden $(57,6 \%)$ dan tidak memiliki pengalaman sebanyak 14 responden $(42,4 \%)$. Semua responden mendapatkan dukungan keluarga yang baik selama menyusui, sedangkan pada pola istirahat responden didominasi oleh pola istirahat yang baik yaitu sebanyak 23 responden $(69,7 \%)$ dan pola istirahat yang kurang sebanyak 10 respoden (30,3\%). Responden yang rutin melakukan perawatan payudara sejumlah 20 repsonden $(60,6 \%)$ dan yang tidak melakukan perawatan payudara sejumlah 13 responden $(39,4 \%)$.

Berdasarkan tabel Tabel 3 didapatkan hasil nilai mean atau rata-rata berat badan bayi sebelum intervensi adalah 5.115,15 gram dengan nilai minimum 1.800 gram dan nilai maksimum 8.200 gram. Nilai mean atau rata-rata berat badan bayi setelah intervensi adalah 5.400 gram dengan nilai minimum 1.700 gram dan nilai maksimum 8.300 gram.

Tabel 3.

Nilai Mean Berat Badan Bayi Sebelum dan Sesudah Intervensi Pijat Oksitosin

\begin{tabular}{cccc}
\hline Variabel & Mean & Nilai Minimum & Nilai Maksimum \\
\hline BB Bayi Sebelum Intervensi & $5.115,15 \mathrm{gram}$ & $1.800 \mathrm{gram}$ & $8.200 \mathrm{gram}$ \\
BB Bayi Setelah Intervensi & $5.400 \mathrm{gram}$ & $1.700 \mathrm{gram}$ & $8.300 \mathrm{gram}$ \\
\hline
\end{tabular}

Tabel 4.

Distribusi Frekuensi Produksi ASI Sebelum dan Sesudah Pijat Oksitosin

\begin{tabular}{lcc}
\hline \multicolumn{1}{c}{ Variabel } & Frekuensi (N) & Persentase (\%) \\
\hline Produksi ASI Sebelum Intervensi & & \\
Baik $(>71 \%-100 \%)$ & 12 & 36,4 \\
Kurang Baik $(<70 \%)$ & 21 & 63,6 \\
Produksi ASI Setelah Intervensi & & \\
Baik $(>71 \%-100 \%)$ & 29 & 87,9 \\
Kurang $(<70 \%)$ & 4 & 12,1 \\
\hline
\end{tabular}

Berdasarkan tabel 4 didapati bahwa produksi ASI sebelum Intervensi didominasi oleh produksi kurang baik yaitu sebesar $63,6 \%$ dan sisanya memiliki produksi ASI yang baik $(36,4)$. Produksi ASI setelah dilakukan intervensi pijat oksitosin mayoritas adalah produksi ASI baik sebesar 87,9\% dan produksi ASI yang kurang baik menurun menjadi $12,1 \%$.

\section{Analisa Bivariat}

Berdasarkan tabel 5 didapatkan bahwa pengaruh intervensi pijat oksitosin dapat meningkatkan produksi ASI sebesar 0,52 yang dari sebelum intervensi sebesar 1,12 menjadi 1,64 setelah dilakukannya intervensi pijat oksitosin. Berdasarkan hasil Uji T dependen didapatkan hasil P-value 0,0001 yang artinya terdapat hubungan yang bermakna antara pemberian pijat oksitosin terhadap peningkatan produksi ASI pada ibu yang menyusui.

Tabel 5.

Pengaruh Pijat Oksitosin Terhadap Peningkatan Kuantitas Produksi ASI Pada Ibu Yang Menyusui Bayi 0-6 bulan

\begin{tabular}{cccc}
\hline Intervensi Pijat Oksitosin & Mean & Standar Deviasi & P-Value \\
\hline Produksi ASI Sebelum Intervensi & 1,12 & 0,331 & \multirow{2}{*}{0,0001} \\
Produksi ASI Setelah Intervensi & 1,64 & 0,489 & \\
\hline
\end{tabular}




\section{PEMBAHASAN \\ Usia Responden}

Berdasarkan hasil penelitian yang dilakukan didapati usia responden mayoritas pada kelompok usia 20-35 tahun, pada kelompok ini merupakan kelompok yang tidak beresiko. Univariat Usia 20 35 tahun merupakan masa produksi yang sehat, dimana keadaan fisik dan mental ibu sedang dalam keadaan paling bagus dan siap untuk menyusui bayinya, perkembangan organ reproduksi sudah sempurna dan matang, sehingga siap untuk memberikan ASI secara eksklusif. Ibu menyusui yang berumur 22 tahun akan lebih banyak memproduksi Asi dibandingkan dengan usia 35 tahun ke atas (Mardiyaningsih, 2011).

\section{Pendidikan}

Berdasarkan hasil penelitian untuk karakteristik pendidikan mayoritas responden berada pada tingkat pendidikan tinggi sebesar $87,9 \%$. Tingkat pendidikan berpengaruh terhadap derajat kesehatan seseorang, terutama pada kelompok keluarga, Pendidikan dapat mempengaruhi kemampuan dan upaya orang tua sehingga lebih mudah untuk mencapai sesuatu. Tingkat pendidikan ibu sangat berpengaruh terhadap kualitas kesehatan keluarga, maka semakin tinggi pendidikan seseorang maka makin baik status kesehatannya ataupun sebaliknya.

\section{Pekerjaan}

Pekerjaan merupakan sesuatu yang dilakukan setiap hari sebagai profesi, sengaja dilakukan untuk menghasilkan penghasilan. Dalam memenuhi kebutuhan primer dan sekunder. Dari hasil penelitian ini didapatkan bahwa sebanyak $57,6 \%$ responden tidak bekerja. Berdasarkan hasil penelitian yang dilakukan oleh Faizatul (2011) memaparkan bahwa ibu yang menyusui bayinya memilih tidak bekerja, karena ingin merawat sepenuh hati dan memberikan ASI eksklusif terhadap bayinya.

\section{Paritas}

Paritas secara luas mencakup gravida/jumlah kehamilan, prematur/jumlah kelahiran, dan abortus/jumlah keguguran. sedang dalam arti khusus yaitu jumlah atau banyaknya anak yang dilahirkan. Pada penelitian ini sebanyak $57,6 \%$ responden berada pada kelompok multipara. Proses menyusui dipengaruhi banyak faktor salah satunya adalah pengalaman menyusui yang didasari oleh jumlah paritas. Ibu dengan paritas dua atau lebih telah mempunyai pengalaman dalam menyusui dan merawat bayinya.
Keberhasilan ibu dalam menyusui anak pertama membuat ibu lebih yakin dapat menyusui anak yang selanjutnya. Keyakinan ibu ini merangsang hormon oksitosin sehingga ASI dapat keluar dengan lancar.

\section{Pengaruh Pijat Oksitosin Terhadap Kuantitas Produksi Asi}

ASI merupakan sumber gizi sangat ideal dengan kompisisi yang seimbang dan disesuaikan dengan kebutuhan pertumbuhan bayi selama enam bulan. Jika seorang bayi tidak diberikan ASI dan diganti dengan susu formula, maka bayi tidak akan mendapatkan kekebalan, serta akan kekurangan gizi. Dengan tidak adanya antibodi, maka bayi akan mudah terkena berbagai penyakit dan meningkatkan angka kematian bayi (Astuty, 2014), namun tidak semua ibu menyusui dapat mengeluarkan ASI yang cukup untuk bayinya dimana faktor penghambat dalam pemberian ASI adalah produksi ASI itu sendiri, keadaan emosi ibu yang berkaitan dengan reflex oksitosin ibu dapat mempengaruhi produksi ASI sekitar $80 \%$ sampai $90 \%$. Kondisi emosional ibu dalam keadaan baik, nyaman dan tanpa tekanan akan dapat meningkatkan dan memperlancar produksi ASI (Rahayu, 2018). Salah satu cara yang dapat dilakukan untuk meningkatkan produksi Asi yaitu dengan melakukan pijat oksitosin yang dapat dilakukan pada ibu menyusui.

Penelitian ini bertujuan untuk meningkatkan produksi melalui teknik pemijatan oksitosin selama 4 minggu yang dilakukan secara berkesinambungan kemudian dilakukan pengukuran sebelum dan sesudah intervensi melalui tanda kecukupan asi dan penambahan berat badan bayi yang dilakukan pada ibu yang memiliki bayi 0-6 bulan. Berdasarkan hasil penelitian yang telah dilakukan menunjukkan bahwa pengaruh intervensi pijat oksitosin dapat meningkatkan produksi ASI sebesar 0,52 yang dari sebelum intervensi sebesar 1,12 menjadi 1,64 setelah dilakukannya intervensi pijat oksitosin. Berdasarkan hasil Uji T dependen didapatkan hasil P-value 0,0001 yang artinya terdapat hubungan yang bermakna antara pemberian pijat oksitosin terhadap kuantitas produksi ASI.

Pijat oksitosin merupakan salah satu solusi untuk mengatasi ketidaklancaran produksi ASI. Pijat oksitosin adalah pemijatan pada sepanjang tulang belakang (vertebrae) dan merupakan usaha untuk merangsang hormon oksitosin setelah melahirkan (Biancuzzo, 2003; Indiyani, 2006; Yohmi \& Roesli, 2009 dalam Mardiyaningsih,2010). Pijatan punggung memberikan efek bagi sistem otot dengan cara memberikan keseimbangan antara relaksasi dan kontraksi. Gerakan pijat punggung 


\section{JKM (Jurnal Kebidanan Malahayati),Vol 7,No.3.Juli 2021, ISSN (Print) 2476-8944 ISSN (Online) 2579-762X, Hal 576-583}

membuat otot dan jaringan lunak merengang dan rileks, mengurangi ketegangan dan kram. Selama proses pijatan punggung, terjadi gerakan relaksasi dan kontraksi yang mengirim sinyal ke otak (hipotalamus), selanjutnya hipotalamus merangsang hifofisis, kemudian hifofisis merangsang saraf parasimpatis untuk mengeluarkan zat kimiawi/hormon dopamine, serotonin, oksitosin, endorphin yang berfungsi untuk relaksasi dan memicu pengeluaran Asi. Pada saat yang sama hipofisis mengurangi hormone kortisol, norepinefrin, epinefrin. Kondisi ini akan meningkatkan perasan seorang terhadap rasa nyaman, menciptakan rasa bahagia, rasa puas, keseimbangan psikomotor, penurunan frekuensi detak jantung, penurunan tekanan darah, peningkatan sirkulasi darah dan limfa sehingga homeostatis tubuh kembali seimbang dan rasa untuk menyusui bayi menjadi meningkat (Rina,2019). Pemberian pijat oskitosin juga memiliki manfaat yang lain seperti menenangkan dan mengurangi stress, membangkitkan rasa percaya diri, membantu ibu agar pikiran dan perasaan yang baik tentang bayinya (Helmy A, 2020).

Hasil penelitian ini juga sejalan dengan hasil penelitian yang dilakukan oleh Ema (2017) menunjukkan bahwa ada pengaruh pijat oksitosin terhadap produksi ASI pada ibu postpartum di wilayah kerja Puskesmas Pejeruk tahun 2017. Hasil penelitian ini menunjukkan bahwa dengan diberikan pijat oksitosin akan lebih memperlancar produksi ASI pada ibu postpartum. Pijatan atau rangsangan pada tulang belakang, neurotransmitter akan merangsang medulla oblongata langsung mengirim pesan ke hypothalamus di hypofise posterior untuk mengeluarkan oksitosin, sehingga payudara mengeluarkan air susu. Melakukan perawatan payudara secara rutin juga dapat mempengaruhi produksi Asi sebanyak 20 responden pada penelitian ini melakukan perawatan payudara secara mandiri dengan menggunakan baby oil dimulai pada masa kehamilan. Hal ini sesuai dengan teori bahwa gerakan pada perawatan payudara bermanfaat melancarkan pengeluaran ASI dan juga secara efektif meningkatkan volume ASI. Produksi ASI dapat dipengaruhi oleh berbagai hal sepertimakanan, frekuensi menyusui, umurkehamilan pada saat melahirkan, berat bayilahir, stres, penyakit akut, konsumsi rokok, pil kontrasepsi (Rukiyah,2015).

Penelitian yang dilakukan oleh Suhertusi pada tahun 2019 tentang peningkatan volume Asi dengan pemijatan oksitosin sejalan dengan penelitian ini. Dimana hasil penelitian Suhertusi didapatkan hasil adanya peningkatan volume ASI sesudah diberikan pijat oksitosin. Pengeluaran ASI dipengaruhi oleh produksi dan volume. Volume ASI dipengaruhi oleh hormon prolaktin sementara pengeluaran dipengaruhi oleh hormon oksitosin. Hormon oksitosin keluar melalui rangsangan ke putting susu melalui isapan bayi atau melalui pijatanpada tulang belakang. Pijatan pada tulang belakang akan membuat tenang, rileks, meningkatkan ambang rasa nyeri dan mencintai, sehingga hormon oksitosin keluar dan ASI pun cepat keluar.

Pada penelitian ini didapatkan hasil ada terdapat peningkatan berat badan pada bayi dimana sebelum dilakukan intervensi bayi dilakukan penimbangan berat badan kemudian setalah dilakukan intervensi bayi juga ditimbang kembali. Dengan nilai mean atau rata-rata berat badan bayi sebelum intervensi adalah $5.115,15$ gram dengan nilai minimum 1.800 gram dan nilai maksimum 8.200 gram. Nilai mean atau rata-rata berat badan bayi setelah intervensi adalah 5.400 gram dengan nilai minimum 1.700 gram dan nilai maksimum 8.300 gram. Hasil penelitian ini sejalan dengan penelitian yang dilakukan oleh Husniah pada tahun 2017 dengan hasil adanya peningkatan berat badan bayi pada kelompok eksperimen dimana rentang kenaikan berat badan mulai dari 200-600 gram dengan rata-rata kenaikan berat badan bayi sebesar 360 gram. Produksi Asi yang cukup dapat meningkatan berat badan bayi dengan melakukan penilaian terhadap tanda kecukupan ASI, diantaranya adalah pengeluaran Asi yangbanyak dapat merembes keluar melalui putting, sebelum disusukan payudara terasa tegang, berat badan bayi naik sesuai umur, Jika ASI cukup, setelah menyusui bayi akan tertidur / tenang selama $3-4$ jam, BAK bayi lebih sering, sekitar 8 sampai 10 kali sehari (Ema, 2017).

Pelaksanaan penelitian ini juga melibatkan peran suami dimana suami juga diajarkan untuk melakukan pemijatan oksitosin kepada ibu, Dari hasil interview dan kuesioner yang diisi responden bahwa semua responden mendapatkan dukungan selama proses menyusui dari suami dan keluarga, namun tidak pernah dilakukukan pijat oksitosin kepada ibu, hal ini disebabkan karena ketidaktauan terkait hal tersebut. Maka pada pelaksanaan intervensi suami diajarkan untuk melakukan pijat oksitosin langsung kepada ibu, sehingga pemijatan dapat dilakukan juga secara mandiri oleh suami. Beberapa responden/ibu merasa senang dan lebih nyaman pemijatan oksitosin langsung dilakukan oleh suami. Hal ini juga sejalan dengan penelitian yang dilakukan oleh Rina (2019) yang menyatakan ada pengaruh pijat oksitosin yang dilakukan oleh 
suami terhadap percepatan pengeluaran ASI. Dari semua dukungan bagi ibu menyusui, dukungan suami adalah dukungan yang paling berarti bagi ibu. Suami dapat berperan aktif dalam keberhasilan ASI eksklusif karena suami akan turut menentukan kelancaran refleks pengeluaran (milk let down reflex) yang sangat dipengaruhi oleh keadaan emosi atau perasaan ibu. Suami dapat memberikan dukungan secara emosional dan bantuan-bantuan praktis (Roesli, 2012).

\section{SIMPULAN}

Ada kenaikan berat badan bayi sebelum dan sesudah intervensi pijat oksitosin pada ibu yang menyusui bayi 0-6 bulan.Ada peningkatan produksi Asi sebelum dan sesudah dilakukan intervensi pijat oksitosin.Ada hubungan pengaruh intervensi pijat oksitosin terhadap peningkatan produksi Asi, hal ini terlihat dari produksi Asi sebelum intervensi dan sesudah intervensi pada ibu yang menyusui bayi 06 bulan.

\section{SARAN}

Bagi peneliti selanjutnya diharapkan dapat menggunakan sampel yang lebih banyak dan jangka waktu pemberian Intervensi yang lebih panjang serta dapat mengembangkan hasil penelitian ini sebagai dasar pada penelitian selanjutnya dalam peningkatan produksi Asi. Dengan adanya penelitian ini dapat menjadi upaya untuk meningkatkan produksi asi, sehingga edukasi kesehatan dapat dilakukan secara berkelanjutan baik dari tenaga kesehatan melalui kelas kehamilan/ prenatal Class sebagai materi wajib yang disampaikan kepada calon ibu bagaimana pijat/ massase oksitosin memberikan manfaat besar dalam proses menyusui. Selain itu informasi tentang pijat oksitosin ini dapat di sosialisasikan dengan baik pada kader kesehatan yang yang ada ditingkat RT

\section{DAFTAR PUSTAKA}

Ambarwati. (2010). Asuhan Kebidanan Masa Nifas. Yogyakarta: Mitra Cendikia Press.

Arief, N. (2009). Panduan Ibu Cerdas ASI dan Tumbuh Kembang. Yogyakarta : Media Pressindo.

Astutik, Reni Yuli. (2014). Payudara dan Laktasi. Jakarta: Salemba Medika.

Biancuzzo. (2003). Breastfeeding the Newborn: clinical stategies for nurse. $\left(2^{\text {th }}\right.$ ed). St Louis: Mosby.
Binarni Suhertusi "Peningkatan volume Asi dengan pemijatan oksitosin" Jurnal IImu Kesehatan (JIK) Volume .4 No. 1 Tahun 2020.

Direktorat Gizi masyarakat, Direktorat Jenderal Kesmas 2018. Buku Saku Pemantauan Status Gizi Tahun 2017, Kesmas.go.id

Danuatmaja B. dan Meiliasari M. (2007). 40 hari Pasca Persalinan, Masalah dan Solusinya. Jakarta: Puspa Swara.

Dewi V. dan Sunarsih T. (2013). Asuhan Kebidanan Pada Ibu Nifas. Jakarta: Salemba Medika.

Ema Pilaria, Rita Sopi "Pengaruh Pijat Oksitosin Terhadap Produksi Asi Pada Ibu Postpartum Di Wilayah Kerja Puskesmas Pejeruk Kota Mataram Tahun 2017", Jurnal Kedokteran Yarsi 26 (1).

Faizatul U. (2011). "Pijat oksitosin untuk mempercepat pengeluaran ASI pada ibu pasca persalinan normal di desa ketanan Kecamatan Gersik"

Farida Juanita1 dkk. (2016). Peningkatan Durasi Pemberian ASI Pada Ibu Post Partum Melalui Relaksasi Autogenic Training. Jurnal Keperawatan Indonesia, Volume 19 No.1, Maret 2016, hal 24-32 pISSN 1410-4490, eISSN 2354-920.

European Food Savety Authority. (2010). Scientific Opinion on Dietaryreference Values For Water. EFSA Journal

Helmy Apreliasari dan Risnawati "Pengaruh Pijat Oksitosin Terhadap Peningkatan Produksi Asi" Jurnal IImiah Kesehatan Kesehatan ArRum Salatiga" Jurnal JIKA Volume 5 Nomor 1 Agustus 2020

King, F.S. (2000). Nutrition For Developing Countries. 2 $2^{\text {nd }}$ Ed. New York: Oxford University Press Inc.

Kemenkes 2018, Rahasia Anak Berkembang Optimal dan Tidak Mudah Sakit: Beri ASI Eksklusif dan Pola Asuh Tepat, http://www.depkes.go.id

Lowdermilk, Bobak \& Jensen. (2006). Buku Ajar Keperawatan Maternitas. (Maria A. Wijayarini., Peter I. Anugrah, Penerjemah). (Edisi 4). Jakarta: EGC

Nichol. K.P. (2005). Panduan Menyusui. (Wilujeng. T.A., Penerjemah). Jakarta: Prestasi Pustakarya.

Mardiyaningsih, E.et al, (2011) "Efektifitas Kombinasi Teknik Marmet dan Pijat Oksitosin Terhadap Produksi ASI" FIK Universitas Indonesia, Jakarta:EGC

Mona, Ratuliu (2014). Buku Pintar ASI dan Menyusui. Jakarta:Mizan Publika. 
JKM (Jurnal Kebidanan Malahayati),Vol 7,No.3.Juli 2021,

ISSN (Print) 2476-8944 ISSN (Online) 2579-762X, Hal 576-583

Musyrifatul Husniyah (2017). "Pengaruh Pijat Oksitosin Terhadap Produksi Asi Pada Ibu Nifas Di Puskesmas Jetis Kota Yogyakarta.

Pace, B (2001). Breastfeeding The Journal of the American Medical Association.

Pilliteri, A. (2003). Maternal \& Child Health Nursing: Care of The Childbearing \& Childbearing Family. (4th Ed). Philadelphia: Lippincott

Poedianto. D.H. (2002). Kiat Sukses Menyusui. Jakarta: Aspirasi Pemuda.

Rahayu D dan Yunarsih, (2018). "Penerapan Pijat Oksitoksin dalam Meningkatkan Produksi ASI Ibu Postpartum". Journals of Ners Community. Volume 09.

Rina Julianti dan Yulia Susanti (2019). Pengaruh Pijat Punggung Yang Dilakukan Oleh Suami Terhadap Percepatan Pengeluaran Asi Pada Ibu Post Partum Hari I Dan Ke II Di Puskesmas Sebrang Padang, Jurnal Penelitian dan Kajian IImiah Menara IImu Universitas Sumatera Barat, DOI: https://doi.org/10.31869/mi.v13i10.162 4.
Rusdianti. (2014). Pengaruh Pijat Oksitosin pada Ibu Nifas Terhadap Pengeluaran ASI di Kabupaten Jember.

Rukiyah, AY, et all, (2015). Asuhan Kebidanan III (Nifas). Jakarta : CV. Trans Info Medis.

Roesli. U. (2005). Mengenal ASI Eksklusif. Jakarta: Trubus Agriwidya

Siregar. A. (2004). Pemberian ASI Ekslusif dan Faktor-faktor yang Mempengaruhinya. Bagian Gizi Kesehatan Masyarakat Fakultas Kesehatan Masyarakat Universitas Sumatera Utara

Soetjiningsih. (2005). ASI, Petunjuk Untuk Tenaga Kesehatan. Jakarta: EGC

Sudoharjo. (2013). ASI Eksklusif. Yogyakarta: Bina Pustaka

Suradi \& Tobing. (2004). Manajemen Laktasi. Jakarta: Perinasia

Hidayat Tutik (2019) Penerapan Metode Massage Endorpin dan Oksitosin Terhadap Peningkatan Produksi ASI Pada lbu Menyusui Bayi 0-6 Bulan Di Desa Gading Kabupaten Probolinggo. The Journal of Health Sciences. Unusa.ac.id 